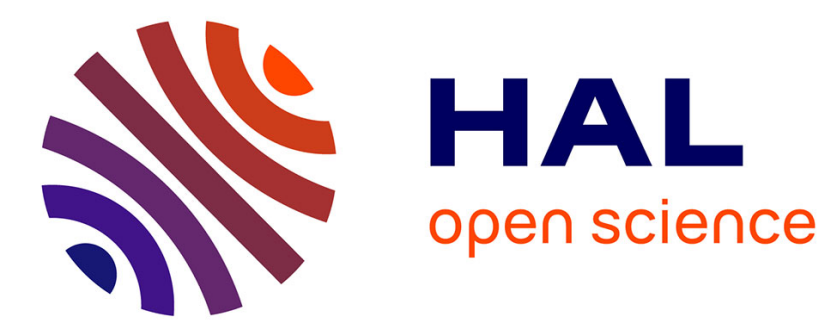

\title{
Theodor Waitz's theory of feelings and the rise of affective sciences in the mid-19th century
}

\author{
David Romand
}

\section{To cite this version:}

David Romand. Theodor Waitz's theory of feelings and the rise of affective sciences in the mid-19th century. History of Psychology, 2015, 18 (4), pp.385-400. hal-03219323

\section{HAL Id: hal-03219323 \\ https://hal.science/hal-03219323}

Submitted on 6 May 2021

HAL is a multi-disciplinary open access archive for the deposit and dissemination of scientific research documents, whether they are published or not. The documents may come from teaching and research institutions in France or abroad, or from public or private research centers.
L'archive ouverte pluridisciplinaire HAL, est destinée au dépôt et à la diffusion de documents scientifiques de niveau recherche, publiés ou non, émanant des établissements d'enseignement et de recherche français ou étrangers, des laboratoires publics ou privés. 
Theodor Waitz's Theory of Feelings and the Rise of Affective Sciences in the Mid-19 ${ }^{\text {th }}$ Century

by David Romand

published in: History of Psychology, 18(4), 2015, 385-400. 
The German psychologist Theodor Waitz (1821-1864) was an important theorist of affectivity in the mid- $19^{\text {th }}$ century. This paper aims to revisit Waitz's contribution to affective psychology at a crucial moment of its history. First, I elaborate the context in which Waitz's ideas were carried out by showing how affective sciences emerged as an autonomous field of investigation between about 1770 and 1910. Second, I discuss the principles of Waitz's model of affectivity and their contextual significance. Third, I deal with the first major category of affective states identified by Waitz, namely, "formal feelings," which are supposed to be involved in the appraisal of the relational properties between representations. Fourth, I investigate "qualitative feelings," the second major category of affective states identified by Waitz, which refer to affective processes that relate to specific representational contents, namely, intellectual, aesthetic, and moral feelings. In conlusion, I emphasize the genealogical link between Waitz's pioneering research on musical feelings and current research on emotion and expectation in music.

Keywords: Theodor Waitz, affective science, history of emotions, feeling, musical expectation 
Theodor Waitz (1821-1864) was an eminent German polymath, who, during his brief career, made significant contributions to philosophy, psychology, anthropology, and the history of religions (Eisler, 1912; Gerland, 1896; Zeller, 1877). Whereas his anthropological thought has been recently revisited (Bunzl, 1996; Jahoda, 2014; Whitman, 1984), Waitz's contribution to psychology has been completely disregarded by historians. In the second half of the $1840 \mathrm{~s}$, the period during which he was active as a psychologist, Waitz published two psychological monographs, the Grundlegung der Psychologie [The Fundamentals of Psychology] (1846) and the Lehrbuch der Psychologie [Textbook of Psychology] (1849) - the latter being a revised version of the former. As a psychologist (Waitz, 1846, 1849), he distinguished himself as a theorist of affectivity, more specifically, as a theorist of feelings (Gefühle), in line with the investigations carried out by Herbart at the beginning of the $19^{\text {th }}$ century (Herbart, 1816/1891, 1825/1892). Waitz was one of the most prominent representatives of "the Herbartian school of affectivity," and should be regarded, more generally speaking, as a typical exponent of the German affective psychology of the mid- $19^{\text {th }}$ century. His developments on aesthetic and moral feelings were exemplary of the rise of affectivity as a cross-disciplinary scientific concern during that period. Valence, appraisal, and the typology of feelings were the three main domains of research to which Waitz contributed significantly as an affective psychologist. Although he had only a few avowed followers (e.g., Nahlowsky, 1862/1884; Volkmann, 1885), Waitz was widely read until the early $20^{\text {th }}$ century and his (direct or indirect) influence is palpable in the work of many theorists of affectivity, in Germany as well as abroad (e.g., Baldwin, 1892; Lehmann, 1892; Lipps, 1902; Wundt, 1910). The Lehrbuch, one of the masterworks of $19^{\text {th }}$-century psychological literature, is particularly remarkable for its extensive theoretical developments (more than 200 pages) on affectivity, that is, basically, the issue of feelings (Gefühle). The present article is a case study that aims to reappraise a major theory of feelings by placing it in 
the context of the emergence of affective sciences and the evolution of ideas on affectivity until the present time.

In the first part, I briefly describe the historical background by demonstrating that affective science, which is classically said to have emerged only recently, is in fact a much older paradigm that was elaborated between the late $18^{\text {th }}$ and early $20^{\text {th }}$ centuries. The second part of the paper is devoted to the theoretical foundations of Waitz's affective psychology, namely: (a) the ontological distinction between affectivity and cognition; the conception of affective states as (b) emergent mental properties and (c) epistemic factors; and (d) the division of affective life into "formal" and "qualitative" feelings. In the third part of the paper, I investigate the psychology of "formal feelings," that is, the affective states that are supposed to emerge from the interactions between representations in consciousness, which Waitz regarded as the most fundamental category of affective processes. The fourth part deals with "qualitative feelings," the category of affective states that result from the "projection" of formal feelings onto definite representational contents, namely, intellectual, aesthetic, and moral feelings. By way of conclusion, I highlight that Waitz's seminal speculations on aesthetic feelings should be regarded as the very beginning of modern psychological and neuroscientific studies on musical expectation.

\section{Historical Background: The Making of a Science of Affectivity (1770-1910)}

\section{Revisiting the Conceptual History of Affective Sciences}

Affective science is typically regarded as a novel field of investigation that has emerged during the last decades as a reaction against the hegemony of cognition in mind and brain research (Gross \& Barrett, 2013; Scherer, 2009). According to this view, it is only recently 
that affective phenomena (i.e., emotions and related mental states) have been studied systematically within a unified cross-disciplinary scientific framework. In reality, such an assumption should be considered cautiously insofar as it corresponds to the "official" viewpoint developed by affective scientists themselves. The thesis that affective science is an unprecedented scientific paradigm can be criticized for being a pro domo argument that consists of contemplating the evolution of affective ideas from a short-term historical perspective. Of course, affective scientists do not deny the early appearance of a scientific and philosophical interest in affectivity; in fact, historians of psychology have pointed out that modern research on affectivity traces its roots back to $19^{\text {th }}$-century psychological studies (e.g., Schönpflug, 2008; Wassmann, 2005). However, considered as a whole, the available literature fails to show convincingly how current affective science is closely related to psychological studies on affectivity carried out between the late $18^{\text {th }}$ and early $20^{\text {th }}$ centuries.

Our vision of how affective science emerged in the long term is relatively biased insofar as historians have tended to privilege English-speaking sources over those from other cultural areas, to focus on some emblematic figures (typically: Darwin and James) who were not necessarily the most representative affective psychologists of their time, and to restrict analysis to the expression and embodiment of emotions, while almost entirely disregarding other crucial affective issues. Moreover, the preeminence of social and cultural approaches in the current history of emotions (Rosenwein, 2010; Stearns, 2008) has clearly diverted historians from examining in detail the psychological stakes of affective concepts. A crucial point that has been largely disregarded by historians is that affectivity developed, from the late $18^{\text {th }}$ century onward, as an autonomous field of investigation within the then-emerging scientific psychology, as testified by the countless psychological handbooks, textbooks, monographs, and papers published during that period (for review, see Eisler, 1910d; Hartmann, 1901). Finally, although scholars have highlighted the role played by affective 
concepts in aesthetics (Allesch, 1987) and linguistics (Knobloch, 1988), they have not fully realized how considerably affective psychology influenced philosophical and social sciences until the beginning of the $20^{\text {th }}$ century (for review, see Eisler, 1910d).

\section{The Early Emergence of a Scientific Paradigm}

Here, I argue that affective sciences are not new but emerged progressively between about 1770 and 1910 and that current research on affectivity is nothing but the resurgence of this old paradigm within the context of modern experimental psychology and neuroscience. Of course, I do not claim that the manner of investigating affective processes one century ago was exactly the same as it is today (the technological context is indeed different in each case). I simply argue that affectivity became, much earlier than usually thought, the topic of a psychologically based, cross-disciplinary research program that shared many epistemological and theoretical commonalities with what modern scholars call "affective science." At the end of the $18^{\text {th }}$ century, German scholars such as Tetens (1777) and Kant $(1798 / 1907)$ identified cognition, affectivity, and volition (conation) as the mind's three chief functional components ${ }^{1}$ - a mental trilogy that structured the psychological thought for more than a century (Hilgard, 1980)². By identifying "affectivity" as a psychological category of its own, psychologists, for the first time in the history, came to clearly distinguish affective phenomena, i.e. feelings (Gefühle), from cognitive phenomena, that is, representations (Vorstellungen $)^{3}$. At the beginning of the $19^{\text {th }}$ century, it became clear that affectivity is not a

\footnotetext{
${ }^{1}$ The German terms“"Erkennen," "Fühlen" (“Gemüt”), and "Wollen” (“Begehren," "Wille”) were usually translated as "cognition" (or "knowledge," "intellect"), "feeling" (or "affection") and "volition" (or "will," "conation") in the English-speaking context. The expression "affectivity" does not seem to have been used during the period considered, but the terms "affection" and "affective" are commonly encountered in the British and American psychological literature of that period (Baldwin \& Stout, 1901a).

${ }^{2}$ Symptomatically, the first part of Kant's Anthropologie (1798/1907) is divided into three books, the first one being devoted to "the cognitive faculty," the second to "the feeling of pleasure and displeasure," and the third to "the conative faculty." The mind's division into cognition, affectivity, and conation was also becoming a structuring dimension of psychological textbooks and handbooks.

${ }^{3}$ Here, I intentionally use the German terminology, which was much more accurate than the English one.

Vorstellung and Gefühl were two typically German terms that did not have any real equivalent in English-
} 
"faculty," but only a collective term that encompasses mental "states" or "processes" likely to be analyzed and explained. By "affective states" or "processes," psychologists were referring to purely subjective psychical phenomena characterized by a definite valence, that is, some degree of attractiveness or aversiveness, by which means we appraise the way of being of representational contents, the mind's objective components (Baldwin \& Stout, 1901a, 1901b, 1902; Eisler, 1910c, 1910d; Stout \& Baldwin, 1901). After having identified affective processes as a specific category of mental states, they came to investigate their nature, their conditions of appearance, and their functional involvement, launching the five chief domains of research of modern affective psychology and neuroscience: (a) subjective feeling, (b) embodiment, (c) expression, (d) appraisal, and (e) action tendency (Sander, 2013; for a historical overview, see Eisler, 1910d and Hartmann, 1901). Interestingly, the rise of affective psychology during the $19^{\text {th }}$ century coincided with the emergence of a specific scientific terminology referring to (a) the new discipline ("affective science," "affective psychology") (b) its main concepts ("affective state," "affective valence," "appraisal," "expression," "affective coloration," "affective tonality," etc.) ${ }^{5}$; and (c) the functional typology of affective states ("epistemic feelings," "aesthetic feelings," "moral feelings," etc.)-a terminology that sounds remarkably "modern" (for comparison, see Eisler, 1910d, Sander \& Scherer, 2009, and Hartmann, 1901). From the mid- $19^{\text {th }}$ century onward, affective psychology became the core of a cross-disciplinary paradigm, integrating, on the one hand, a variety of biological and medical disciplines (Wassmann, 2005), and exerting, on the other, a strong impact on many

\footnotetext{
speaking psychology. They were approximatively translated into a variety of terms: Vorstellung into "presentation," "representation," "idea," "conception," or "image"; Gefühl into "feeling," "emotion," or "sentiment" (Baldwin \& Stout, 1902; Eisler, 1910f; Stout \& Baldwin, 1902). It is worth noting that it is only at the turn of the $19^{\text {th }}$ century that the term "Gefühl" came to be used systematically and unambiguously to refer to the functional components of affective life.

${ }^{4}$ By Gefühlslehre (literally: "doctrine of feeling”), German scholars were referring to, since the early $19^{\text {th }}$ century, the psychological-based investigation of all aspects of affective life, and this term should therefore be regarded as an early equivalent of "affective science". "Affective psychology", which first appeared in the German literature (Gefühlspsychologie), was commonly used in late $19^{\text {th }}$ and early $20^{\text {th }}$ centuries.

${ }^{5}$ The expression "affective valence" (Gefühlswert, literally: "affective value") pertained to the classic terminological repertoire of German affective science in the $19^{\text {th }}$ and early $20^{\text {th }}$ centuries. Contrary to the other expressions mentioned here, it does not seem to have been used in the English-speaking context.
} 
philosophical and social sciences (Eisler, 1910d). It is worth noting that affective psychology turned out to be, in late the $19^{\text {th }}$ century, an experimental science, whose methods and techniques have continued and developed uninterruptedly until present day (Schönpflug, $2008)^{6}$.

\section{The Principles of Waitz's Affective Psychology}

In order to understand the principles of Waitz's affective psychology, it is necessary to take into account two important elements of context. ${ }^{7}$ On the one hand, it should be kept in mind that Waitz was a typical exponent of the German paradigm of affectivity as it has emerged since the end of the $18^{\text {th }}$ century. Characteristically, the German psychologists of that time advocated a mentalistic and analytic approach to affectivity, the question here being how the components of affective life, feelings (Gefühle), interact with each other and with representations in order to contribute to the appearance of psychical functions. German affective psychology was basically a theory of feelings; here, "feeling" is a generic term that should be distinguished both from "emotion" (Affekt) — which specifically refers to the sudden and mighty manifestation of feelings in consciousness ${ }^{8}$ - and from sensation (Empfindung)-the constitutive elements of representations (for the specificities of the German school, see Lehmann, 1892; Ribot, 1896). On the other hand, one should be aware of the fact that Waitz was one of the chief representatives of the so-called Herbartian school of affective psychology. In $19^{\text {th }}$-century affective psychology, "the Herbartians" (die Herbartianer)

\footnotetext{
${ }^{6}$ This raises the question of why the first paradigm of affective sciences disappeared around1910, a historical phenomenon that lies in the crisis that affected psychological thought during the first decades of the $20^{\text {th }}$ century (Romand, 2009).

${ }^{7}$ The following developments are based on a commentary on the Lehrbuch der Psychologie, which is representative of Waitz's mature psychological thought.

${ }^{8}$ Traditionally, such a distinction does not exist in British and American affective psychology, in which the use of the terms and concepts is much less formalized than in the German tradition (Baldwin \& Stout, 1901b; Stout $\&$ Baldwin, 1901). Nevertheless, in late $19^{\text {th }}$ and early $20^{\text {th }}$ centuries, many English-speaking psychologists tended to use the terms "feeling" and "emotion" in accordance with German use.
} 
referred to an informal group of scholars (among them Waitz, Volkmann, and Nahlowsky) who shared a theory of feelings directly inspired from the model outlined by Herbart $(1816 / 1891,1825 / 1892)$ at the beginning of the $19^{\text {th }}$ century. The core of the Herbartian doctrine of affectivity was the view that feelings are emergent processes of the mind that arise from the interactions between representations. Two other specific traits of the school consisted of considering affective states as high-level mental properties and dividing affective life into "formal" and "qualitative" feelings.

\section{Affective Versus Cognitive Processes}

In the Lehrbuch, Waitz assumed a strict separation between cognition (Erkennen) and affectivity (Fühlen, Gemüth) ${ }^{9}$ and regarded representations (Vorstellungen) and feelings (Gefühle) as the two essential constitutive elements of psychical life. By "cognition," he referred to all psychical processes that mediate access to knowledge through the apprehension of a definite object. Cognition was said to be "sensory" or "intellectual" according to whether the object we apprehend immediately appears to us as an image of the external world or is experienced as a product of our own mental activity. In the first instance, we have to do with sensory representations (Sinnesvorstellungen), that is, mental states that give us the impression that they occur independently from our own conscious activity and that we spontaneously refer to as something existing externally to us. In the second instance, we have to do with concepts (Begriffe), that is, mental states that we interpret as manifestations of our own interiority, while recognizing them as the indirect expression of some external reality. Whether perceived or conceived, the content of consciousness is in both cases apprehended objectively.

\footnotetext{
${ }^{9}$ In the $19^{\text {th }}$-century German psychological tradition, the terms Fühlen and Gemüt were often used interchangeably to refer to the mind's function that mediates the manifestations of affective life (Eisler, 1910e).
} 
By contrast, feelings are devoid of any "positive content" and therefore are not likely to be rendered by words. They constitute a category of fully inexpressible mental states that, as Waitz said, should be regarded as the inalienable property of the individual's consciousness. Just like concepts, they belong to inner psychical life, that is, to the subjective forms of conscious awareness, but unlike them, and contrary to representations in general, they do not express anything but themselves. Feelings are always experienced confusedly as something that manifests itself more or less agreeably or disagreeably in consciousness. As subjective manifestations of consciousness, feelings also differ from concepts in that they are not associated with any effort of the will and cannot be altered by it. As Waitz emphasized, affectivity alienates us, in contrast to thinking, in which we behave freely ${ }^{10}$.

\section{Feelings as "Epistemic" Factors}

Waitz supported a strictly mentalistic approach of affectivity and regarded affective processes as nonsensory properties. In this respect, he insisted on the fact that feelings should not be confounded with sensations (Empfindungen), the primitive data mediated by external stimulations or limb movements that serve to elaborate of representational contents. Sensations, as the immediate effects of the stimuli on the mind, depend on the organic processes that occur in the nervous substance and, therefore, ultimately require a physiological explanation. In contrast to sensibility (Empfinden), affectivity (Fühlen) cannot be analyzed except in psychological terms. Feelings are experienced as mere alterations of the conscious activity that occur concomitantly with the manifestation of sensory contents. Nevertheless, as Waitz remarked, feelings and sensations appear to be inextricably entangled

\footnotetext{
${ }^{10}$ Waitz also insisted on the necessity of considering affectivity in relation to desire (Begehren). According to him, affective and appetitive processes are not essentially different from each other and cannot be analyzed separately: Every feeling is always accompanied by some desire, while the fact of desiring necessarily involves a feeling of wanting.
} 
in ordinary conscious life and the two kinds of phenomena are in reality hardly separable from each other by introspection.

On the other hand, Waitz departed from the standards of the affective science of his time by assuming that feelings are purely spiritual (geistige) conscious phenomena, that is, mental states that contribute in many respects to the mind's intellectual powers. Here, he disagreed with the traditional division of affective life into "sensory" (sinnliche) and "spiritual" (geistige) feelings ${ }^{11}$. More specifically, he criticized Herbart's assumption that bodily pleasure and pain are mediated by specific feelings and that they should be analyzed in merely psychological terms (Herbart, 1816/1891, 1825/1892). Against Herbart and, in fact, most contemporary German psychologists, Waitz maintained that pleasurable and painful phenomena that relate to one's own bodily states are inherent to the sensory activity and therefore reducible to nervous processes. According to him, a clear-cut distinction should be made between bodily pleasure and pain, on the one hand, and between spiritual pleasure and pain, on the other.

In the psychological model of affectivity advocated by Waitz, feelings basically appear as the carriers of particular forms of knowledge. They consist of a variety of semantic properties added to representational knowledge in order to make the flow of representations experientially significant and to contribute to the elaboration of high-level cognitive functions. As Waitz alleged, affective life should be logically regarded as developing in parallel with intellectual life. The maturation of the child's affective powers consists of the progressive dominance of intellectual interests (intellectuelle Interessen) to the detriment of purely sensory interests. According to him, feelings are derived (abgeleitete) phenomena of

\footnotetext{
${ }^{11}$ Since Kant (1798/1907), the distinction between sensory (lower) and spiritual (intellectual, higher) feelings was regarded as a classic division of affective life (for review, see Hartmann, 1901). According to this view, one should distinguish between low-level feelings that accompany the appearance of perceptual processes and highlevel feelings that relate to more abstract and elaborated aspects of conscious life. Importantly, the so-called sensory feelings (often called "sense-feelings" by contemporary English-speaking psychologists) were not supposed to be sensory properties, but merely affective processes that double up sensory activity (and notably bodily sensibility) in order to increase its experiential relevancy. Waitz considered the sensory feeling hypothesis as unfounded.
} 
psychical life that accompany the manifestation of cognitive activity from the moment when it has achieved some level of development. Unlike cognition, affectivity is a nonreflexive kind of knowledge that is significant only as long as it is apprehended concomitantly with cognitive processes, since feelings themselves have no autonomous existence separate from representational activity ${ }^{12}$.

\section{Feelings as Emergent Properties of the Mind}

Waitz regarded affective processes as a kind of psychological "by-product" of representational activity, that is, more specifically, as the result of the conflicting interactions that are supposed to happen between representational contents when they encounter and combine with one another. In other words, feelings are experiential properties that occur correlatively with the incessant coming and going of representations in consciousness. "The cause of their appearance," Waitz explained, “can only lie in the form of the representational power, in the way in which something is represented, in the way of producing representations" (Waitz, 1849, p. 291) ${ }^{13}$. Feelings are by no means determined by the nature of the representational contents, as they are not reducible to the modifications of the representational activity and therefore should not be identified with representations themselves. In line with Herbart (1816/1891, 1825/1892), Waitz advocated an emergent view of affective processes. He shared with Herbart the common idea that feeling is a mental state

\footnotetext{
${ }^{12}$ The various kinds of affective states identified by Waitz and, more generally speaking, by the Herbartian school, consist of what modern scholars use to call epistemic or cognitive emotions (feelings), that is, "emotions such as confusion, interest, surprise, or awe [that] particularly relate to knowledge and learning" (Sander, 2013, p. 14). Contrary to what is usually assumed, neither the concept, nor the expression of "epistemic (cognitive) feeling (emotion)" is new. The idea that there is a class of affective states that mediate an intuitive and abstract form of knowledge (such as expectation, doubt, novelty, or surprise) was explicitly contemplated by Tetens in the second half of the $18^{\text {th }}$ century (Tetens, 1777). These kinds of affective states, generally known as the "feelings of truth" or "logical feelings," generated considerable interest among psychologists until the beginning of the $20^{\text {th }}$ century (for review, see Eisler, 1910d). The expression "emotion of knowledge" was coined in the mid-1 $9^{\text {th }}$ century by Bain (1875). In the German-speaking context, Horwicz (1878) proposed the term Erkenntnissgefühl (literally: "knowledge-feeling"), while Meinong (1894) spoke of Wissensgefühl (literally: "knowing-feeling").

${ }^{13}$ All translations are mine.
} 
whose appearance "depends on nothing but the way and circumstances in which the representation comes into consciousness" (Waitz, 1849, p. 295) and does not require any further psychological or physiological explanation. In other words, feelings have the property of manifesting themselves spontaneously in consciousness as soon as definite conditions inherent to representational life are fulfilled. Albeit fundamentally distinct from representations, affective processes are mere epiphenomenal properties that never occur independently from cognitive processes. In this respect, they have no specific anatomical substrates and relate to the nervous system only insofar as representations are themselves mediated by it. The issue of embodiment was irrelevant in Waitz's theory of feelings, which is by no means surprising since it was only with Lotze some years later that anatomy and physiology became major concerns of affective psychology (Lotze, 1852).

According to this view, each alteration in representational activity results in the emergence of a definite feeling, so that we should be assailed at any moment by a great number of effective states as long as representations flow in consciousness. As Waitz emphasized, this is actually not the case, insofar as most affective processes that occur in consciousness remain inaccessible to introspection. This is particularly true in the case of feelings that accompany the ordinary rhythm of representational life, such as the feelings of tension (Gefühl der Spannung), effort (Anstrengung), or fatigue (Mühe) that usually remain unnoticed unless they are scrutinized carefully. Generally speaking, it is only when significant obstacles interrupt the flow of representations that affective activity becomes experientially relevant. This happens when

the changes of representations are too quick and too violent for the mind to be able to seize completely the content of what is represented, or too slow and too idle for it to be in charge of the content (...) that comes into consciousness. (Waitz, 1849, p. 298). 
When this does not happen, feelings manifest themselves too transiently in consciousness to be noticed. More precisely, Waitz (1849) maintained that "feelings become noticeable only insofar as the mind finds its representational activity inhibited at a given point, when it refrains from immersing itself completely in what is represented" (Waitz, 1849, p. 298).

\section{The Twofold Typology of Feelings}

In the Lehrbuch, Waitz proposed a systematic analysis of affective life by reviewing the various kinds of feelings that are supposed to accompany the flow of representations and to contribute to all the manifestations of ordinary conscious life. According to him, one should distinguish two main classes (Klassen) of feelings according to whether they specifically accentuate the formal relationships between representations ("formal feelings") or are experienced in relation to definite contents of consciousness ("qualitative feelings"). ${ }^{14}$ The two classes of feelings differ from each other in their mode of appearance in consciousness as well as in their functional implications. Whereas the second class consists of three consistent subclasses of well-defined affective processes (intellectual feelings [or feelings of truth], aesthetic feelings, moral feelings), the first class appears to be a more or less disorganized set of various kinds of feelings.

\section{The Psychology of Formal Feelings}

\footnotetext{
${ }^{14}$ In the Lehrbuch zur Psychologie (1816/1891), Herbart distinguished between "the feelings that depend on the mood" and "the feelings that are attached to what is felt," without proposing any specific terminology. Waitz (1849) coined the expression "formal feeling" (formales Gefühl) to refer to Herbart's first class of affective states. Nahlowsky (1862/1884) was the first to contrast "qualitative feelings" (qualitative Gefühle) with "formal feelings" (formal- or formelle Gefühle), while Volkmann (1885) preferred to speak of "vague" and "fixed feelings" (vage/fixe Gefühle).
} 


\section{The Nature and General Properties of Formal Feelings}

The first class of feelings identified by Waitz encompasses all affective processes that occur in consciousness without being related to any representational content in particular (Waitz, 1849, pp. 301-333). Such feelings are never associated with the apprehension of definite perceptual or conceptual properties. They do not help "color" individual representations, but highlight the way in which they interact as they follow one another in consciousness. The only thing these feelings are concerned with is the form of the flow of representations, and in this respect, they can be qualified as formal feelings (formale Gefühle). Because it does not relate to the qualitative nature of the contents of consciousness, the kind of knowledge conveyed by formal feelings appears to be irreparably destroyed as soon as we try to reflexively analyze the representational relationships that determine its appearance. The so-called formal feelings mediate a variety of more or less short-lived states of awareness that are likely to be experienced at all times in ordinary conscious life, such as expectation, doubt, impatience, boredom, and so forth. These apparently secondary psychological phenomena are in reality of crucial importance for the proper unfolding of the individual's cognitive skills.

\section{Typological Analysis of Formal Feelings}

Waitz admitted that it was not possible, in the context of the then current psychological research, to propose a complete typological analysis of formal feelings. Instead of establishing a true taxonomy of formal feelings, he simply enumerated a variety of affective states while insisting on the functional commonalities that may exist between them. Nevertheless, Waitz's intention was not simply to describe the various kinds of formal feelings, but to explain them psychologically by specifying their conditions and modalities of appearance in consciousness. 
In this respect, he tried to highlight the representational processes that are supposed to underlie the manifestation of each kind of feeling.

The most primitive and the most important kind of formal feeling is, according to Waitz, the feeling of expectation (Gefühl der Erwartung). By "feeling of expectation," Waitz referred to the particular state of awareness by which means the individual anticipates the achievements of his or her own conscious life. The feeling of expectation is a feeling of mental tension that occurs when a series of representations ${ }^{15}$ that mediate the unfolding of a regular external event are reproduced. When appearing in consciousness, the perceptual elements that compose the series tend to recall, by virtue of the laws of association, the subjective images of the elements that are next to them in the series. As a result, each perceptual image is preceded by its corresponding subjective image, which remains for some time in consciousness before being fused with it. This transient persistence of internally generated representations is, according to Waitz, the psychical mechanism that determines the appearance of the feeling of expectation. More precisely, this occurs when the last member of a definite series of representations appeals to us internally for a short time before being apprehended as a perception. As Waitz emphasized, feelings of expectation appeal to us at any time, even if most of them remain unnoticed because they are satisfied too quickly by the process of fusion.

Generally speaking, Waitz termed the feeling of satisfaction (Gefühl der Befriedigung) as the affective state that results from the identification of a subjective image with its perceptual content. But expectation may be resolved without being satisfied. This is the case when the element of a series is replaced by a perceptual content that was not expected. Here, the feeling of expectation turns into another kind of affective state, the so-called feeling of deception (Gefühl der Täuschung).

\footnotetext{
${ }^{15}$ In Herbart's psychology, a "series" (Reihe) referred to a train of elementary representations (sensations) that are likely to be reproduced in the same order in which they were associated.
} 
Waitz explained the appearance of the other kinds of formal feelings in a similar manner by analyzing the specific representational processes that are supposed to underlie them. All formal feelings distinguished by Waitz are in reality more or less directly subsumable under the concept of expectation. They derive from the feeling of expectation and from the way in which the latter is satisfied or deceived. Describing the mode of appearance of each formal feeling would be laborious and of limited interest. Suffice it to say that in this respect, for Waitz, fatigue, strain, trouble, wanting, doubt, irritation, impatience, boredom, contrast, disgust, and so forth were further affective states that belong to the category of formal feelings. In any case, formal feelings cannot be listed accurately, insofar as each species is likely to be transformed into another and to yield a variety of intermediary forms.

\section{The Psychology of Qualitative Feelings}

\section{The Nature and General Properties of Qualitative Feelings}

In contrast with formal feelings, the second class of feelings postulated by Waitz consists of affective processes whose main characteristic is to be apprehended together with definite representational contents (Waitz, 1849, pp. 333-415). Although these feelings, like any other manifestation of affective life, are devoid of any proper content, they exist in consciousness only as long as the individual is able to connect them to particular kinds of representations. As Waitz explained, they have the property of being "projected" (projicirt) onto the contents of consciousness, that is, of being associated with them in order to alter their experiential significance. The projection of feelings onto representations is the hypothetical psychological mechanism that confers a definite coloration to the latter and determines the functional specificity of the former. Since these feelings do not reflect the formal 
characteristics of the flow of representations, they are always experienced in relation to welldefined experiential qualities, and in this respect can be called "qualitative feelings." The socalled qualitative feelings are by nature theoretically ascribable to any kind of representational content. In reality, Waitz considered that there are only three main cognitive domains to which they can be referred, namely, truth, beauty, and morality. He used the terms "intellectual", "aesthetical", and "moral" for the three corresponding subclasses of qualitative feelings.

Because of their close relationships with representational contents, qualitative feelings also differ from formal feelings in that their disappearance from consciousness does not necessarily imply the disappearance of the knowledge they mediate. When experiencing a definite qualitative feeling, the individual apprehends the object of affectivity and the object of cognition as one unique thing. Analytical reasoning about the object of affectivity results in the immediate destruction of the qualitative feeling while leaving more or less unaltered the corresponding representational content. In the process of thinking, the object of affectivity becomes a mere object of cognition because in that case, affective states are entirely substituted by conceptual relationships. Here, Waitz insists on the necessity of not confounding the kind of knowledge associated with qualitative feelings with the one that is mediated by thinking. Qualitative feelings occur when conceptual analysis is not likely to be performed thoroughly, that is, when the individual is unable to reach the conclusion of what he is thinking about. They correspond to a more or less obscure form of knowledge that precedes or follows the manifestation of thinking. As Waitz emphasized, "[the qualitative] feeling is just an auxiliary to cognition but does not serve to ground it directly" (Waitz, 1849, p. 336). Qualitative feelings nonetheless remain essential to the unfolding of matured conceptual life. 


\section{Intellectual Feelings or Feelings of Truth}

The first subclass of qualitative feelings distinguished by Waitz, the so-called intellectual feelings (intellectuelle Gefühle) or feelings of truth (Gefühle der Wahrheit), was analyzed only briefly in the Lehrbuch (Waitz, 1849, pp. 309-311, 336-340). As the name indicates, feelings of truth are affective processes that have to do with the experience of truth, that is, that are specifically associated with the apprehension of the theoretical forms of knowledge. Like qualitative feelings in general, they occur correlatively with unclear representational contents in the absence of well-defined conceptual relationships. Typically, intellectual feelings are those affective states that accompany the unfolding of demonstrative processes that are too long to be apprehended explicitly in consciousness. In that case, reasoning manifests itself elusively and it is only by means of affectivity that the individual is able to estimate its validity. As Waitz emphasized, feelings of truth serve only as provisional support to theoretical knowledge and draw back from consciousness as soon as we succeed in reconstituting the corresponding conceptual relationships. When attaining the concept that we were looking for, we gain an "insight" (Einsicht) that replaces what we knew only implicitly by means of intellectual feelings. More precisely, this results from the incomplete comparison of the individual representations that are instantiated during reasoning with the general representational types that we assume to be the norm of the case in question.

Our capacity to apprehend the agreements and disagreements between these kinds of contents determines the appearance of two antagonistic affective states that Waitz called feeling of rightness (Gefühl der Richtigkeit) and feeling of falseness (Gefühl der Unrichtigkeit). It is on the basis of these two feelings that we are able to appraise the correctness of an expression in a foreign language, grammatical differences, and conceptual nuances, but also the psychological truth of a character during a performance. Waitz 
distinguished another form of intellectual feelings: the feeling of likelihood (Gefühl der Wahrscheinlichkeit) and its experiential counterpart, the feeling of unlikelihood (Gefühl der Unwahrscheinlichkeit). In this respect, he insisted on the necessity of not confounding philosophical likelihood, which is assessed on the basis of affective processes, with mathematical likelihood, which results from a purely conceptual activity.

\section{Aesthetic Feelings}

Nature and General Properties of Aesthetic Feelings. As Waitz emphasized in the many pages of the Lehrbuch devoted to aesthetic feelings (ästhetische Gefühle; Waitz, 1849, pp. 340-388), the role of the psychologist is to explain the origin of the aesthetic contentment (ästhetisches Wohlgefallen) that the individual experiences when apprehending definite forms or structures (Gestalten). In contrast with sensory contentment (sinnliches Wohlgefallen), aesthetical contentment does not depend on sensory elements per se, but on the way in which they are organized in consciousness according to the structural properties of space and time. Aesthetic feelings are nothing but the feelings of pleasure that mediate the so-called aesthetic effect of forms (ästhetische Wirkung der Gestalten). ${ }^{16}$ That is why, in Waitz's view, only sight and hearing are likely to evoke aesthetic feelings. More specifically, the aim of psychological aesthetics is to determine the way in which definite affective processes may be induced by the apprehension of spatial and temporal forms.

Nevertheless, Waitz insisted on the fact that aesthetic research is not exhausted by psychology, because aesthetic feelings are never experienced independently from sensory data, whose investigation, as seen earlier, lies within the competency of physiology. Aesthetic feelings are always accompanied non only by pleasurable or nonpleasurable sensations, but

\footnotetext{
16 “Aesthetic contentment" and "aesthetic effect" were two expressions typical of the $19^{\text {th }}$-century psychological aesthetics.
} 
also by other kinds of affective processes, namely, moral feelings, which manifest themselves more or less agreeably or disagreeably in consciousness ${ }^{17}$.

Aesthetic feelings in the visual arts. Waitz's theory of aesthetic feelings is based first and foremost on an analysis of visual aesthetic phenomena (Waitz, 1849, pp. 340-353). The aesthetic effect of visual forms basically concerns space perception; more precisely, it depends on the capacity to apprehend geometrical figures. When contemplating, say, a triangle, our eye, which follows the outlines of the figure, experiences a feeling of deception each time it encounters an angle instead of the line expected. Because the figure is regular, we are able to anticipate the occurrence of this subjective disturbance by reproducing the corresponding series of representations, which results in a feeling of expectation. This feeling helps to diminish the disturbance and is immediately replaced by a pleasurable feeling of satisfaction. Not all kinds of regular figures are likely to evoke aesthetic feelings with the same strength. A polygon with numerous sides is experienced as monotone and induces a feeling of boredom instead of a feeling of satisfied expectation. Moreover, the angles are in that case not marked enough and the sides are too short to produce a sufficiently powerful aesthetic effect. The neatness of the figures and the possibility of apprehending them as a whole are, according to Waitz, two further important conditions of the manifestation of aesthetic feelings. In addition to space perception, Waitz considered motion perception as an additional factor of the aesthetic effect of forms ${ }^{18}$.

Aesthetic feelings in music. Regarding musical aesthetics, Waitz chiefly investigated the role of affective processes in rhythm and melody (Waitz, 1849, pp. 353-388). Rhythm consists of an organized succession of auditory representations that vary in length and intensity. As such, rhythmical forms are not likely to produce any aesthetic effect; only if they

\footnotetext{
${ }^{17}$ Here, Waitz agreed with Herbart's view that aesthetic experience does not exist but through the "total impression" made by organic sensations and affective processes that occur together at a given moment (Herbart, 1825/1892).

${ }^{18}$ Waitz's speculations on the ability of aesthetic feelings to change according to the perception of simple geometric figures directly foreshadowed the experimental protocols developed by Fechner within the framework of his experimental aesthetic (Fechner, 1876).
} 
are accompanied with aesthetic feelings do we experience them with contentment or discontentment. For Waitz, the aesthetic effect induced by rhythmical forms basically depended on the same affective process as that induced by visual forms. Here too, aesthetic feelings can be referred to the manifestation of a feeling of expectation and its subsequent satisfaction.

Rhythm is a regular perceptual phenomenon whose return to consciousness can be anticipated on the basis of a feeling of expectation, which manifests itself once the corresponding series of representations has been reproduced. When repeated too uniformly, rhythmic forms, like geometrical figures, give us an impression of monotony and are accompanied by a feeling of boredom instead of an aesthetic feeling. Because in that case we are sure that the expectation will be satisfied, we remain almost unaware of the tension that precedes the satisfaction. As Waitz emphasized, the strength of the feeling of expectation largely depends on our ability to be doubtful about whether it is going to be satisfied or not. Generally speaking, the aesthetic effect of rhythm should be regarded as the result of a subtle balance between the possibility of satisfying and the effective satisfaction of the feeling of expectation. ${ }^{19}$

Waitz discussed only briefly the issue of the aesthetic effect of melodies. According to him, melodic forms, which consist of a series of qualitatively different auditory representations, are characterized by their ability to evoke feelings of expectation. The effect of melodic forms proves to be particularly powerful just before the exposition of the main theme and at the moment when the piece is ending.

In contrast to rhythm and melody, harmony basically requires, according to Waitz, a physiological explanation and therefore does not directly relate to the issue of aesthetic feelings. Unlike rhythmic and melodic forms, the harmonic unit does not consist of a

\footnotetext{
${ }^{19}$ It is worth noting that Waitz's investigations on the relationships between rhythm and affectivity did not exclusively relate to music but also concerned prosody.
} 
temporally organized series of representations, but simply a sum of sensory data given to us simultaneously in the instantaneity of consciousness. In other words, harmony results from the apprehension of a "formless" grouping of auditory sensations, which is ultimately determined by the nature and arrangement of nervous fibers. The pleasure we spontaneously feel when perceiving a chord is purely sensory contentment that depends only on the organization of the acoustic nerve. However, at the same time, Waitz admitted that the perception of harmony is not entirely reducible to physiological considerations: Besides our innate capacity to experience chords, we may also be endowed with an acquired ability to apprehend the relationships between sounds. According to him, the psychological perception of harmony is proper to the educated ear and is characterized by a much higher acuteness than that of physiological perception. More specifically, it consists of discriminating the constitutive elements of a chord while estimating the "distance," that is, the degree of subjective opposition, that exists between them. In addition to perceiving the sounds simultaneously, the trained individual is able to analyze their harmonic relationships by apprehending them successively in consciousness. Here, harmony relates to the manifestation of an auditory form whose aesthetic effect is mediated by specific affective processes. According to Waitz, the aesthetic feelings by which we appraise harmony result from our capacity to compare the impression we get when psychologically decomposing a chord with the primary impression we get when perceiving it as an unanalyzed unit ${ }^{20}$.

\section{Moral Feelings}

According to Waitz, we experience a moral feeling (sittliches Gefühl) from the moment when the image of someone else's mind-set (Gesinnung) appears to us as a definite power that

\footnotetext{
${ }^{20}$ Strangely enough, Waitz did not specify the nature of the affective mechanisms involved, but it may be reasonably hypothesized that in this case he thought about the feeling of contrast.
} 
has an influence on our own representational life (Waitz, 1849, pp. 388-415). As explained at length in the Lehrbuch, the emergence of moral feelings and their subsequent differentiation are the result of a complex psychogenetic process. Although it is not possible to review Waitz's sophisticated developments in detail, I will make some brief comments about them.

Basically, moral behavior originates in the child's ability to interact with surrounding objects, onto which the child "projects" his or her own feelings so that they become the focal point of affective activity. Other individuals represent for the child a particular class of objects, something living and acting about which the child learns to anticipate the favorable or unfavorable behavior towards him or her. More specifically, the child is able to take into account the existence of other people's mind-sets as soon as he or she experiences a "feeling of doubtful expectation" (Gefühl der zweifelnden Erwartung).

From that moment on, the image we have of the other's mind-set becomes capable of inhibiting or activating the series of representations that guide our actions relating (or seeming to relate) to the individuals who face us. When performing an action that contravenes the power that they exert on us, we can, instead of thinking about the person concerned, simply experience the affective state that is associated with the person, the so-called feeling of authority (Gefühl der Autorität). The moral character of the feeling of authority, Waitz explained, "occurs as soon as the impulse to act, which is contained in it, conflicts with other impulses, namely, sensory desires" (Waitz, 1849, p. 394). At this level of development, the feeling of authority would become a subjective norm with which our individual actions endeavor to comply.

Nevertheless, Waitz remarked, "the true morality (Moralität) and the beginning of wisdom" is obedience (Gehorsam), that is, "the submission of the individual will to the power, internally recognized as compelling, of the law that is given by somebody else and that is brought by his/her authority" (Waitz, 1849, pp. 396). When our individual volition does not 
submit itself to the prescriptions of the law, we experience an internal contradiction while violating the authority. In that case, there is a conflict between the representation of what we have done and the representation of what we should not have done, which results in the manifestation of an unpleasant feeling of remorse (Gefühl der Reue). Moreover, Waitz proposed interesting developments on sympathy (Mitgefühl, Sympathie), that is, the subject's ability to experience analogically the affective states of others, which, in contrast to the feeling of obedience, he regarded as the practical basis of morality. As he emphasized, it is only on the basis of our own inner activity that we are able to interpret the expression of the other person's mind-set.

Finally, we reach the last step in the elaboration of moral feelings when we realize that we can influence the affective states of others by acting on them, just as others can act on our own affective states. As Waitz emphasized: "It is only from the moment when we have a representation of this intrusion on the personality's interiority (...) that we get a complete image of the relationships between the individuals" (Waitz, 1849, p. 399) ${ }^{21}$.

Taken together, Waitz's developments on moral feelings had to do with the theory of Einfühlung ("empathy") and were more or less directly inherited from Herder, who already emphasized the role of feelings in the experience of other individuals (Herder, 1778). Nevertheless, as a theorist of Einfühlung, ${ }^{22}$ Waitz clearly distanced himself both from the Romantic and idealist traditions, insofar as he tried to explain animacy and intersubjectivity in purely psychological terms, and from contemporary aestheticians such as F. T. Vischer, insofar as he regarded Einfühlung, not as a specific property of aesthetic consciousness, but as

\footnotetext{
${ }^{21}$ According to Waitz, the psychogenetic process described earlier ends in the appearance of many kinds of moral feelings: the feeling of the immorality of lying (Gefühl der Unsittlichkeit der Lüge), the self-respect feeling (Ehrgefühl), the justice feeling (Rechtsgefühl), the injustice feeling (Unrechtsgefühl), the feeling of equity (Gefühl der Billigkeit), the feeling of gratitude (Gefühl der Dankbarkeit), and the feeling of goodwill (Gefühl des Wohlwollens). For each category of feelings, Waitz proposed a detailed psychological analysis that does not seem particularly relevant for discussion in the context of the present article.

${ }^{22}$ It is worth noting that neither the substantive Einfühlung (which was coined by R. Vischer in the 1870s), nor the verb einfühlen (already used by Herder in the late $18^{\text {th }}$ century) is encountered in the Lehrbuch.
} 
a basic and ubiquitous function of the mind (on the genealogy of the concept of Einfühlung, see Edwards, 2013; Jahoda, 2005). ${ }^{23}$

\section{Conclusion: Waitz as a Pioneer of the Affective Theory of Musical Expectation}

Waitz was indisputably one of the most important theorists of feeling of the $19^{\text {th }}$ century and among the scholars who had the most decisive impact on the elaboration of the paradigm of affective sciences. Among his many pioneering contributions to the issue of affectivity, his assumption that each kind of affective state is endowed with a specific experiential quality besides pleasure and displeasure should be regarded as the origin of "the multidimensional theories of feeling" that developed in the late $19^{\text {th }}$ and early $20^{\text {th }}$ centuries (Lipps, 1902; Wundt, 1896, 1910). Wundt's tridimensional theory (Wundt, 1896, 1910), according to which the qualitative manifoldness of feelings results from the interplay between the three directions of pleasure/displeasure, tension/relief, and arousal/inhibition, and Lipps' conception that affective life consists of countless opposite qualities (Lipps, 1902), owed much, in all likelihood, to the model of affectivity advocated by Waitz and, more generally speaking, by the Herbartian school. Lipps, who implicitly supported the view that feelings are emergent properties of the mind, seems to have been particularly indebted to Waitz, probably through his direct and most influential heir, Nahlowsky (1862/1884).

Here, I would like to mention a word about an important field of investigation of which Waitz was, to the best of my knowledge, the first to lay the foundations: the role of expectation and related feelings in the aesthetic experience of music.

\footnotetext{
${ }^{23}$ In this respect, Waitz's theory of moral feelings can be said to be based on an early model of what modern scholars calls "theory-of-mind,", that is, "the branch of cognitive science that investigates how we ascribe mental states to other persons and how we use the states to explain and predict the actions of those other persons" (Marraffa, 2011).
} 
As discussed earlier, Waitz explained the aesthetic effect of rhythms and melodies on the basis of the feeling of expectation and its dialectic relationship to the feeling of satisfaction. In particular, we saw that the fact of maintaining a state of tension and doubt contributes to the enhancement of aesthetic contentment. According to Waitz, the various kinds of musical feelings originate in our capacity to anticipate the recurrence of "forms" or “structures" (Gestalten) by recalling definite series of auditory representations ${ }^{24}$. Among the immediate upholders of Waitz's theory of musical feelings, one should mention Wundt (1911), who further theorized Waitz's assumptions while launching the first experimental research program on the issue of expectation in music. ${ }^{25}$ Wundt's studies on musical aesthetics were largely devoted to the so-called rhythmic feelings, the affective processes that accompany the rhythmic organization of sounds and that, according to him, consist of intensive variations of "tension" (Spannung) and "relief" (Lösung) in parallel with those of pleasure (Lust) and displeasure (Unlust; Wundt, 1911). The temporal unfolding of rhythmic feelings can be investigated experimentally in order to build "affective curves"-an experimental paradigm that springs directly from the research program on temporal representations developed in the Leipzig laboratory. In all likelihood, the studies carried out

\footnotetext{
${ }^{24}$ Here, Waitz interpreted the aesthetic experience of music in terms of "elementary aesthetic feelings" (ästhetische Elementargefühle), that is, qualitatively defined affective processes that are supposed to accompany the constitutive elements of aesthetic objects and to interact with each other in order to produce a global aesthetic effect (Eisler, 1910b, 1910c). This analytical conception of aesthetic feelings contrasted with the much more holistic one advocated by most German aestheticians until the beginning of the $20^{\text {th }}$ century (for review, see Lalo, 1910). The theory of elementary aesthetic feelings was developed further by Nahlowsky $(1862 / 1884)$, who coined the expression, and Wundt (1911).

${ }^{25}$ Albeit conceptually rather obvious, the link between Waitz and Wundt on the role of the feeling of expectation in music remains difficult to establish from a philological point of view, because, to the best of my knowledge, Wundt did not mention the Lehrbuch in his developments on musical aesthetics. Generally speaking, Wundt's late theory of aesthetic feelings appears to be much influenced by Nahlowsky (1862/1884), from whom he borrowed many typical concepts and expressions such as "elementary aesthetic feeling", "partial feeling", "total feeling", and "feeling of form" (yet without referring to him explicitly). Nevertheless, regarding the special case of musical expectation, it seems more reasonable to maintain that Waitz was his immediate source of inspiration, insofar as the issue of musical feeling was not much developed by Nahlowsky. As mentioned in the introduction, Wundt's mature theory of feelings derived, in all likelihood, from the Herbartian affective psychology. Although Wundt quoted the Lehrbuch here and there (e.g., Wundt, 1910, p. 373), his multidimensional model of feeling originated most probably in Das Gefühlsleben [The Affective Life], the influential monograph in which Nahlowsky further developed Waitz's qualitative analysis of feelings (Nahlowsky, 1862/1884). But here, too, Wundt made no explicit reference.
} 
by Wundt and his pupils provide the genealogical link between Waitz's pioneering ideas and modern research on music, emotions, and expectation.

The study of expectation-related effects is nowadays recognized as a major concern in the affective science of music, both psychologists and neuroscientists being interested in how surprise, tension, deception, premonition, relief, and so forth shape our musical experience (Huron, 2006; Narmour, 1992). As Huron and Margulis explain in Juslin and Sloboda's Handbook of Music and Emotion: "In the history of scholarship pertaining to music and emotion, the phenomenon of expectation has occupied a central and perhaps privileged position," and, in fact, "[n] early all psychologists working in the field of music cognition have carried out experiments that bear directly on the issue of expectation," an issue that "many music scholars have addressed (...)" as well (Huron \& Margulis, 2010, pp. 575 and 583-584). While acknowledging the importance of expectation in the history of musical aesthetics, Huron and Margulis totally disregard the above-mentioned studies carried out within the context of German psychology. According to them, the affective theory of musical expectation is a field that emerged only recently and that simply did not exist before the late 1950s. More specifically, it should be dated back, in their view, to the publication of Emotion and Meaning in Music by Leonard Meyer (1956), the musicologist who is commonly regarded as the "founding father" of expectation studies:

Meyer was far ahead of his time in integrating cognitive and affective aspects of mental functioning. In drawing attention to the importance of expectation, Meyer anticipated the conclusions of cognitive neuroscience by half a century. Meyer was a lone voice, largely out of step with mainstream current in both musicology and psychology. (Huron \& Margulis, 2010, p. 586) 
This assumption has been uncritically accepted by modern specialists of the field and, to the best of my knowledge, no historian of psychology has hitherto explored the $19^{\text {th }}$-century origins of musical expectation studies.

My aim is not to deny Meyer's importance as a theorist of musical expectation, but to relativize the innovativeness of his views by placing them in the long-term evolution of psycho-aesthetic ideas. Meyer's developments were, as a whole, clearly reminiscent of Waitz's speculations on the role of expectation in music, even if the theory proposed in Emotion and Meaning in Music was much more sophisticated than the model sketched in the Lehrbuch. For Meyer, expectation basically consisted of "a tendency to act," whose inhibition evokes a variety of affective processes. More specifically, these affective states emerge from the dynamic organization of musical patterns (melody, rhythm, meter, harmony, etc.), which are combined with each other and organized hierarchically. Although the expectation-related effects originate in Gestalt-like properties, ${ }^{26}$ our capacity for being satisfied or dissatisfied with music is not innate but depends on our familiarization with styles and the establishment of stylistic norms. It is worth noting that, whereas he at no time mentions Waitz, Meyer alludes to Wundt, whom he reproaches for reducing the aesthetic effect of music to pleasure and displeasure, which is a complete misunderstanding. Moreover, he refers several times to Bissell's thesis, The Role of Expectation in Music (Bissell, 1921), a work he quotes only briefly but which seems to have been one of his major sources of inspiration. In this remarkable monograph, Bissell discusses Wundt's studies on rhythm and their close relatedness to the American tradition in the psychology of music. Here, I have sketched the genealogical path that leads from Waitz's Lehrbuch to the most recent psychological and neuroscientific research on musical expectation.

\footnotetext{
${ }^{26}$ Ironically, Meyer's reference to "Gestalt" laws to explain the phenomenon of expectation seems to have to do much more with Waitz than with the Gestaltist tradition he refers to more or less rhetorically.
} 


\section{References}

Allesch, C. G. (1987). Geschichte der psychologischen Ästhetik [History of psychological aesthetics]. Göttingen: Verlag für Psychologie.

Bain, A. (1875). The emotions and the will (3rd ed.). London, UK: Longmans, Green.

Baldwin, J. M. (1892). Handbook of psychology: Vol. 2. Feeling and will. New York, NY: Holt.

Baldwin, J. M., \& Stout, G. F. (1901a). Affectiona and affective. In J. M. Baldwin (Ed.), Dictionary of philosophy and psychology (Vol. 1, pp. 21-22). New York, NY: Macmillan.

Baldwin, J. M., \& Stout, G. F. (1901b). Feeling. In J. M. Baldwin (Ed.), Dictionary of philosophy and psychology (Vol. 1, p. 377). New York, NY: Macmillan.

Bissel, A. D. (1921). The role of expectation in music. A study in the psychology of music. (Doctoral dissertation). St. Louis, MO: Hugues Print.

Bunzl, M. (1996). Franz Boas and the Humboldtian tradition: From Volksgeist and Nationalcharakter to an anthropological concept of culture. In G. Stocking (Ed.), Volksgeist as method and ethic: Essays on Boasian ethnography and the German anthropological tradition (pp. 17-78). Madison, WI: University of Wisconsin Press.

Edwards, L. H. (2013). A brief conceptual history of Einfühlung: $18^{\text {th }}$-century Germany to post-World War II U.S. psychology. History of Psychology, 16, 269-281. https://doi.org/10.1037/a0033634

Eisler, R. (1910a). Affekt [Emotion]. In Wörterbuch der philosophischen Begriffe, historischquellenmässig ( $3^{\text {rd }}$ ed., Vol. 1, pp. 14-18). Berlin, Germany: Mittler. 
Eisler, R. (1910b). Ästhetik [Aesthetics]. In Wörterbuch der philosophischen Begriffe, historischquellenmässig (3 ${ }^{\text {rd }}$ ed., Vol. 1, pp. 102-117). Berlin, Germany: Mittler.

Eisler, R. (1910c). Ästhetische Elementargefühle [Elementary aesthetic feelings]. In Wörterbuch der philosophischen Begriffe, historischquellenmässig ( $3^{\text {rd }}$ ed., Vol. 1, p. 117). Berlin, Germany: Mittler.

Eisler, R. (1910d). Gefühl [Feeling]. In Wörterbuch der philosophischen Begriffe, historischquellenmässig (3 ${ }^{\text {rd }}$ ed., Vol. 1, p. 391-400). Berlin, Germany: Mittler.

Eisler, R. (1910e). Gemüt [Affectivity]. In Wörterbuch der philosophischen Begriffe, historischquellenmässig ( $3^{\text {rd }}$ ed., Vol. 1, p. 414-415). Berlin, Germany: Mittler.

Eisler, R. (1910f). Vorstellung [Representation]. In Wörterbuch der philosophischen Begriffe, historischquellenmässig (3 ${ }^{\text {rd }}$ ed., Vol. 3, pp. 1690-1699). Berlin, Germany: Mittler.

Eisler, R. (1912). Waitz, Theodor. In Philosophen-Lexikon. Leben, Werke und Lehre der Denker (p. 801). Berlin, Germany: Mittler.

Fechner, G. T. (1876). Vorschule der Aesthetik [Prolegomena to aesthetics]. Leipzig, Germany: Beitkopf \& Härtel.

Gerland, G. (1896). Waitz, Theodor. Allgemeine Deutsche Biographie (Vol. 40, pp. 629-633). München, Germany: Duncker \& Humblot.

Gross J. J, \& Barrett, L. F. (2013). The emerging field of affective science. Emotion, 13, $997-$ 998. https://doi.org/10.1037/a0034512

Hartmann, E. v. (1901). Von Empfindung, Gefühl und Wille [On sensation, feeling, and will]. In H. von Hartmann (Ed.), Ausgewählte Werke von Eduard von Hartmann. Bd. 13, Die moderne Psychologie (pp. 174-279). Leipzig, Germany: Haacke. 
Herbart, J. F. (1891). Lehrbuch der Psychologie [Textbook of psychology]. In K. Kerbach (Ed.), Johann Friedrich Herbart's Sämmtliche Werke, in chronologischer Reihenfolge (Vol. 4, pp. 295-436). Langensalza, Germany: Beyer (Original work published 1816).

Herbart, J. F. (1892). Psychologie als Wissenschaft neu gegrundet auf Erfahrung, Metaphysik und Mathematik, Zweiter, analytischer Teil [Psychology as a science, newly founded on experience, metaphysics, and mathematics, second, analytical part]. In K. Kerbach (Ed.), Johann Friedrich Herbart's Sämmtliche Werke, in chronologischer Reihenfolge (Vol. 6, pp.1-338). Langensalza, Germany: Beyer (Original work published 1825).

Herder, J. G. (1778). Vom Erkennen und Empfinden der menschlichen Seele. Bemerkungen und Träume [On the cognition and sensation of the human mind. Comments and reveries]. Riga, Latvia: Hartknoch.

Hilgard, E. R. (1980). The trilogy of mind: Cognition, affection, and conation. Journal of the History of the Behavioral Sciences, 16, 107-117. https://doi.org/10.1002/15206696(198004)16:2<107::AID-JHBS2300160202>3.0.CO;2-Y

Horwicz, A. (1878). Psychologische Analyse auf physiologischer Grundlage. Ein Versuch zur

Neugründung der Seelenlehre. Zweiter Theil, zweite Hälfte. Die Analyse der qualitativen Gefühle [Psychological analysis on physiological basis. An attempt to refound psychology. Second part, second half. The analysis of qualitative feelings]. Madgeburg, Germany: Faber.

Huron, D. (2006). Sweet anticipation: Music and the psychology of expectation. Cambridge, MA: MIT Press. 
Huron, D., \& Margulis, E. H. (2010). Music, expectancy, and thrills. In P.N. Juslin \& J. A. Sloboda (Eds.), Handbook of music and emotion: Theory, research, applications (pp. 575604). Oxford, UK: Oxford University Press.

Jahoda, G. (2005). Theodor Lipps and the shift from "sympathy" to "empathy." Journal for the History of the Behavioral Sciences, 41, 151-163. https://doi.org/10.1002/jhbs.20080

Jahoda, G. (2014). Theodor Waitz on psychic unity. Integrative Physiological and Behavioral Science, 48, 176-203. https://doi.org/10.1007/s12124-013-9255-x

Kant, I. (1907). Anthropologie in pragmatischer Hinsicht. In Kant's gesammelte Schriften (Vol. 7, pp. 117-333). Berlin, Germany: Reimer (Original work published 1798).

Knobloch, C. (1988). Geschichte der psychologischen Sprachauffasung in Deutchland von 1850 bis 1920 [History of the psychological conception of language in Germany from 1850 to 1920$]$ ]. Tübingen, Germany: Niemeyer. https://doi.org/10.1515/9783111371689

Lalo, C. (1910). Les sentiments esthétiques [The aesthetic feelings]. Paris, France: Alcan.

Lehmann, A. (1892). Die Hauptgesetze des menschlichen Gefühlslebens. Eine experimentelle und analytische Untersuchung über die Natur und das Auftreten der Gefühlszustände nebst einem Beitrage zu deren Systematik [The essential laws of human affective life. An experimental and analytical investigation on the nature and emergence of affective states, including a contribution to their taxonomy] (translated from the Danish by F. Bendixen in collaboration with the author). Leipzig, Germany: Reisland.

Lipps, T. (1902). Vom Fühlen, Denken und Wollen. Eine psychologische Skizze [On affectivity, thinking, and volition. A psychological outline]. Leipzig, Germany: Barth.

Lotze, E. H. (1852). Medicinische Psychologie oder Physiologie der Seele [Medical psychology or physiology of the mind]. Leipzig, Germany: Weidmann. 
Marraffa, M. (2011). Theory of mind. In Internet Encyclopdia of Philosophy. Retrieved from http://www.iep.utm.edu/theomind/

Meinong, A. (1894). Psychologisch-ethische Untersuchungen zur Werth-theorie [Psychological-ethical investigations on the theory of value]. Graz, Austria: Leuschner \& Lubenski.

Meyer, L. B. (1956). Emotion and meaning in music. Chicago, IL: Chicago University Press.

Nahlowsky, J. W. (1884). Das Gefühlsleben. In seinen wesentlichsten Erscheinungen und Bezügen dargestellt [Affective life, considered in its most essential phenomena and conditions] (2nd ed.). Leipzig, Germany: Veit (Original work published 1862).

Narmour, E. (1992). The analysis and cognition of melodic complexity: The implicationrealization model. Chicago, IL: University of Chicago Press.

Ribot, T. (1896). La psychologie des sentiments [The psychology of feelings]. Paris, France: Alcan.

Romand, D. (2009). Vygotski lecteur critique de Stern. La question du transfert de la psychologie allemande en Russie dans le contexte épistémologique des années 1910-1930 [Vygotsky's critical reading of Stern. The issue of the transfer of German psychology to Russia in the epistemological context of the years 1910-1930]. In D. Romand \& S. Tchougounnikov (Eds.), Psychologie allemande et sciences humaines en Russie. Anatomie d'un transfert culturel (1860-1930), Revue d'Histoire des Sciences Humaines, 21, 103-126.

Rosenwein, B. (2010). Problems and methods in the history of emotions, Passions in Context: Journal of the History and Philosophy of the Emotions, 1. Retrieved from http://www.passionsincontext.de/index.php?id=557 
Sander, D. (2013). Models of emotion: The affective neuroscience approach. In J. L. Armony \& P. Vuilleumier (Eds.), The Cambridge handbook of human affective neuroscience (pp. 553). Cambridge, UK: Cambridge University Press. https://doi.org/10.1017/CBO9780511843716.003

Sander, D., \& K. R. Scherer (Eds.). 2009). The Oxford companion to emotion and the affective sciences. Oxford, UK: Oxford University Press.

Scherer, K. R. (2009). Affective science. In D. Sander \& K. R. Scherer (Eds.), The Oxford companion to emotion and the affective sciences (pp. 16-17). Oxford, UK: Oxford University Press.

Schönpflug, W. (2008). Aus den Anfängen der experimentellen Emotionspsychologie [On the origin of the experimental psychology of emotions]. In W. Janke, M. Schmidt-Daffy, \& G. Debus (Eds.), Experimentelle Emotionspsychologie. Methodische Ansätze, Probleme, Ergebnisse (pp. 47-62). Lengerich, Germany: Pabst.

Stearns, P. N. (2008). History of emotions: Issues of change and impact. In M. Lewis, J. M. Haviland-Jone, \& L. F. Barrett (Eds.), Handbook of emotions (3rd ed., pp. 17-31). New York, NY: Guilford Press.

Stout, G. F., \& Baldwin, J. M. (1901). Emotion. In J. M. Baldwin (Ed.), Dictionary of philosophy and psychology (Vol. 1, pp. 316-317). New York, NY: Macmillan.

Stout, G. F., \& Baldwin, J. M. (1902). Presentation. In J. M. Baldwin (Ed.), Dictionary of philosophy and psychology (Vol. 2., p. 333). New York, NY: Macmillan.

Tetens, J. N. (1777). Philosophische Versuche über die menschliche Natur [Philosophical essay on human nature] (2 vols.). Leipzig, Germany: Weidmann. 
Volkmann, W. F. v. (1885). Lehrbuch der Psychologie vom Standpunkte des Realismus und nach genetischer Methode [Textbook of psychology from the point of view of realism and according to the genetic method] (4th ed., Vol. 2). Cöthen, Germany: Schulze.

Waitz, T. (1846). Grundlegung der Psychologie [Fundamentals of psychology]. Hamburg, Germany: Perthes.

Waitz, T. (1849). Lehrbuch der Psychologie als Naturwissenschaft [Textbook of psychology as a natural science]. Brauschweig, Germany: Vieweg.

Wassmann, C. (2005). The science of emotion: Studying emotions in Germany, France, and the United States, 1860-1920 (Unpublished doctoral dissertation). University of Chicago, Chicago, IL.

Whitman, J. (1984). From philology to anthropology in mid-nineteenth-century Germany. In G. W. Stocking (Ed.), Functionalism historicized, essays on British social anthropology, history of anthropology (Vol. 2, pp. 214-229). Madison, WI: The University of Wisconsin Press.

Wundt, W. (1896). Grundriss der Psychologie [Outline of psychology] (1st ed.). Leipzig, Germany: Engelmann.

Wundt, W. (1910-1911). Grundzüge der physiologischen Psychologie [Principles of physiological psychology] (6th ed., Vol. 2 \& 3). Leipzig, Germany: Engelmann.

Zeller, E. (1877). Drei deutsche Gelehrte, 2. Theodor Waitz [Three German scholars, 2. Theodor Waitz]. In E. Zeller (Ed.), Vorträge und Abhandlungen, Zweite Sammlung (pp. 363-373). Leipzig, Germany: Fues. 